\title{
Study on Film and Television Literature Criticism
}

\author{
Xinxin Li \\ Henan Vocational College of Agriculture \\ Zhengzhou, China 451450
}

\begin{abstract}
The emergence of film and television literature criticism is inextricably linked with the historical development of film and television. Film and television literature criticism can be said to run through every stage of the film and television development in the world. The establishment of interactive relationship among the fields of technological system, art form and social structure of film and television will be helpful to open up the research field of film and television literature criticism. Also, it also benefit from the overall development, enrichment and improvement of film and television literature criticism. It is a discipline independently. And it will inevitably call for formal consideration of its own characteristics, functions, the subject and object, viewpoint, paradigm and text type. Strictly speaking, film and television literature criticism should belong to the category of literature criticism. However, film and television are comprehensive art. It is the complex of arts such as literature, drama, music, painting, sculpture and architecture. Therefore, it is impossible for film and television literature criticism to talk about art without jumping out of the category of literary aesthetics. Nowadays, with the continuous development of film and television, and the integration of various high and new technology and new aesthetic, the subject of film and television literature criticism becomes extremely complicated. The film and television literature criticism involves social morals, popular culture, psychoanalysis and feminism. Also, it directly has dialogue with current science and technology. Here, film and television literature criticism has completely surpassed the shackles of literary aesthetics. And it has rose to the height of technical aesthetics.
\end{abstract}

\section{Keywords—film and television literature; criticism; study}

\section{INTRODUCTION}

The so-called film and television literature criticism is a basic discipline that explores the principles of film and television criticism. Its object of the research is film and television criticism. The main contents of research include the features of film and television criticism, the function of film and television criticism, the subject and object of film and television criticism, the viewpoint of film and television criticism, the paradigm and text of film and television criticism critics, and so on. The establishment of film and television literature criticism is the inevitable request of the history of film and television development for more than 100 years. Also, it is the objective demand of the criticism theory, film and television theory and the practice of film and television criticism. After all, the film and television literature criticism with distinctive film and television features also needs its own comparatively perfect theory system of criticism. At present, the limitations of film and television theory in criticizing practice and the individualization of criticizing methods all affect the sound development of film and television literature criticism to a certain extent. Therefore, the construction of film and television literature criticism is not groundless. It is the trend of history. Also, it is the real needs.

Broadly speaking, film and television literature criticism can refer to all the writing related to film and television works and the arts. And it includes various popularized film review such as the criticism on newspapers and magazines, the interactive criticism between the television media and the Internet, and the seminars on impression of view. Narrowly, film and television literature criticism refers to the application of various humanities and social sciences theory and methodology as well as the theory of film and television literature to analyze the film and television works and phenomenon, to reveal the universal rules and guide the academic practice activity of film and television creation. In this sense, film and television literature criticism belongs to the category of filmology. And it has the same position with that of the study of film and television theory and the history of film and television. It has dependent value and status.

\section{THE CHARACTERISTICS AND FUNCTIONS OF FILM AND TELEVISION LITERATURE CRITICISM}

\section{A. The Characteristics of Film and Television Literature Criticism}

Film and television literature criticism belongs to a branch of literary criticism. It has the generality of general literary criticism. Also, it has the uniqueness of screen art criticism. Generally, the several characteristics of the film and television literature criticism are shown as the followings.

1) Cultural characteristic: Culture regulates the significance of living behaviors of human beings. According to the opinions of British scholar Marinnovsky, culture is simply the reality of means and the cumulative creation of mankind. Also, it increases the individual efficiency and the power of action. With such a profound thought and ambitious vision, culture profoundly changes the innate conferment of mankind. Therefore, he has made a conclusion. People should grasp the possible art and its accepted investigation to maintain the cultural type of society. It is possible to see the complexity and depth in the phenomenon of artistic acceptance. And then, people would 
further be close to the understanding of the inherent cultural mechanisms. Only in this way, we can make the analysis of the modernity of artistic reception and its feasibility obtained in futuramic and advanced feelings. Therefore, art is inextricably linked with society, subject, and culture all the time.

In general, to explore the cultural psychology of specific ethnic culture, to reveal the regional cultural characteristics in the film and television phenomenon, to explore the myths and rituals in the film and television works, and to analyze the cultural conflicts and cultural changes in the film and television works are the specific characteristics of the film and television literature criticism.

2) Industrial characteristics: People pay attention to the characteristics of the industrial research of film and television literature criticism. In the specific theory and practice of film and television literature criticism, it fully follows the features of industrial production and commercial operation of film and television, and actively pays attention to the production, distribution and screening / broadcasting of film and television. Based on the theory of modern enterprise management, industrial organization theory and marketing theory, it deeply studies the development strategy of the film and television industry and the law of economic operation. Of course, the mirror study and cultural analysis are incomplete without the industrial research for the film and television literature criticism. Similarly, industrial research must also be combined with the mirror study and cultural analysis. And then, it would avoid misunderstandings of "seeing only the forest, not the trees" in the process.

With the needs of economic development and cultural development, the restructuring of the world media industry is also on the upsurge. This reorganization reflects the industry characteristics of film and television. In recent years, media acquisitions have continuously evolved from the inner industry to multiple industries, from domestic acquisitions to cross-border mergers and acquisitions, from developed countries to the world, and from horizontal mergers to vertical mergers and acquisitions. The cross-reorganization of various media is also attracting attention. The U.S. broadcasting and television industry has a high degree of concentration and monopoly. At present, the 25 largest media groups in the United States include super information dissemination groups of broadcasting, television, cable television, satellite broadcasting and television, newspapers, magazines, the publishing, movie, record, entertainment, telephone, Internet, sports, retail, advertising and other industries. The film and television industry group has two features. First, it belongs to the multimedia industry group. And it integrates newspapers, television, radio, the publishing, audio and video. Second, it is to rapidly have the expansion through mergers and acquisitions. The industrialization of film and television is coincident all over the world. And we should study the experience gained in the development of film and television industry in other countries. Due to the industrialization of film and television, film and television literature criticism has to have its own characteristics.

3) Film and television literature criticism is the commentary on the main object of film and television works: In his article "On criticism", Pushkin said: "Criticism is the science that reveals the beauty and shortcomings of literary and artistic works. It is based on full understanding of the rules obeyed by the artists or writers in their work, the role of models in research, and the positive observation of contemporary salient phenomena. Here, Pushkin's object of discussion is literary criticism. Apparently, it also could be applied to the criticism of film and television. Film and television literature criticism can also be said to reveal the beauty and shortcomings of film and television works. On the one hand, the comment object first refers to the specific film and television works. Second, it can also include the film and television arts phenomenon related to the film and television art works, such as the evaluation of film and television artists, discussion on various elements of film and television composition, introduction of film history school and ideological trend and so on. Of course, the focus of film and television literature criticism is film and television works. All writing that completely separates from the film and television works is not the true film criticism. On the other hand, film and television literature criticism is mainly based on film and television works. It must be accompanied by the characteristics of "film and television" in its operation. For example, in the content, it must reflect the observers' understanding and familiarity with the film and film features and the knowledge of film and television. In the works and artistic phenomena, we must follow the artistic laws of film and television.

4) Film and television literature criticism is a form of appreciation activities: From the perspective of aesthetic, film and television art appreciation activities is the process of complete aesthetic understanding and aesthetic judgment. In this process, the appreciators come into contact with the film and television works through their own senses. And then, they would have the aesthetic perception. They could get certain understanding of the aesthetic association, aesthetic imagination and the aesthetic emotion. Finally, they would obtain the aesthetic judgment and evaluation through the aesthetic synthesis. That is to say, they have completed the appreciation of the film and television. The completion of film appreciation can be broadly divided into two situations. One is the individual completion. It is mainly reflected in the individual aesthetic appreciation and aesthetic understanding of the film and television. Movie appreciators watch movies and television works through their own senses. And these film and television works would help them understand the characters and events with their artistic accomplishments, aesthetic experiences and life experiences. Then, they would obtain certain aesthetic understanding and aesthetic judgments. When the appreciators feel that they have indeed comprehended and 
understood the thoughts and art of film and television work, this kind of aesthetic appreciation activity, which is purely personal aesthetic appreciation activity, can also be said to have basically been completed. Of course, this kind of aesthetic understanding and aesthetic harvest will also subtly transform into certain spiritual force. It would have certain influence on his behaviors. With the deepening of his life, artistic practice and emotional activity, his aesthetic understanding and aesthetic harvest will be continually linked with the new aesthetic harvest. And it would be more fulfilling, rich and deep. The other is the completion of the socialization. In this form, the film and television appreciators will turn their own aesthetic harvest into material and cultural form - film and television literary criticism.

\section{B. The Function of Film and Television Literature Criticism}

The functions of film and television literature criticism generally reflect in guiding the audience, stimulating the creation and promoting the popularization of film and television.

1) The guidance on the audience's appreciation: Film and television art is an intuitive, visual and modern art. Also, it is the most popular art. A large number of audiences are the premise and guarantee for the survival, development and prosperity of film and television arts. On the other side of the question, large number of audience almost includes all levels of people. The lower-level people account for a large proportion. Due to the low cultural level, these people lack the necessary film and television knowledge and artistic accomplishment. They also have considerable shortcomings in comprehending the connotation of film and television works, the meanings of film and television programs, and the understanding of film and television arts skills. Moreover, due to the complexity of moral concepts, ideological qualities, life experience, cultural and psychological structure, social attitudes and other aspects, a considerable number of people stick to the tradition. And they have the old and narrow sights. In the appreciation activities of film and television arts, it is likely to form the barrier of the acceptance. Due to various reasons, even those who have relatively high levels of culture would know little about the artistic characteristics, laws and specialties of film and television. It will also make them become layoffs for film and television art appreciation. In the face of the unique forms of innovation, the rich connotation of the content of the film and television works, their understanding will often attempt an ineffective solution. And they would even have the misunderstanding. Therefore, it requires film criticism to guide and help the audience.

The main task of film and television literature criticism is to reveal the ideological and artistic features of film and television works and to appraise their ideological and artistic value. At the same time, film and television literature criticism also has the responsibility of "interpreting works of art and cultivating aesthetics". And then, it would "bring them into completely negligible facts". Outstanding film criticism can make more objective and comprehensive interpretation of the film and television works from a rational perspective. It would guide the audience to better appreciate various types of film and television works, including the more artistic ones.

2) Incentives for film and television creators: The incentives of film and television literature criticism for film and television creators mainly reflect in two aspects. First of all, after the completion of the creation of film and television creation, creators often strongly desire to recognize the value judgments of the audience and critics on their works. They not only need to confirm their own value through the comments, but also need to see their own deficiencies through the comments, and understand the current expectations and interest of the audience. For the film and television creator, what the most distressed is the indifference and silence of the audience on his works. Speaking of his works, Gogol said: "How I wish everyone could point out my shortcomings and problems to me! Even if they are rude, outspoken, biased, angry and resentful, whatever they do, I want their opinions". He believes that "one who is determined to point out the ridiculousness of others should reasonably accept the weaknesses and ridiculousness that others have pointed out to themselves". This will not only significantly promote the connotation of film and television works, but also greatly extend the film and television works. Some film and television works with concealed artistic connotations and controversial content often attract audience's interest due to being criticized or controversial. This precisely enlarges the influence of these films on the contrary.

3) The promotion for the popularization of film and television culture: Film and television art has significant modern meaning. Compared with the audiences of traditional art, it has the popular aesthetic taste. Also, it is the most popular communication media in the world today. It has its own special cultural character in terms of artistic form and information dissemination. In order to make the most of the audience understand the film and television works correctly and deeply, it all depends on the popularization and improvement of cultural knowledge of film and television. At present, the overall level of national culture in China, especially the popularization of film and television culture, is not high. And it lags behind the modern life and the world trend. Therefore, film and television criticism, which takes the responsibility of judging film and television works, should take the lead in popularizing the film and television culture. It should bear the burden of disseminating the knowledge of film and television, correcting the audience's misunderstanding, spreading the correct method and skill of reading film and television works, and improving the aesthetic appreciation of the masses. Through the practical activities of film criticism, it 
should constantly deepen and develop film and television art theory. Also, it would play an important role in the construction of national film and television culture.

\section{THE MODE OF FILM AND TELEVISION LITERATURE CRITICISM}

\section{A. The Model of Social Criticism}

1) Ethics and moral criticism: The ethics and moral criticism model of film and television is a typical model of film and television social criticism. It aims at judging the ethical and moral contents of the film. And it takes the ethical and moral values of religious culture such as Christianity, Islam, or Confucianism as the main criticism criterion, and adopts the criticism of doctrinal declaration and moral warning. In the film and television industry all over the world, the film / television inspection system from official or cinematographer associations is often the strong support and the fundamental basis of the film and television ethics and moral criticism. Among them, the Hollywood famous "Hayes Code" is a typical example.

Around 1929, the Hollywood star system reached its peak. The bold dress and inattention of many film stars have begun to provoke public resentment and criticism. And the religious circles, which take the Catholic as the leader, have also attacked the Hollywood movies politically and morally. For example, in the case of "sexual" prohibition, the Hais Code states that we should concern for the sanctity of marriage and family. The love triangle is the love of a married third party. The film and television must be treated with caution so that the audience wouldn't be disgusted with the marriage system. The handling of the love scene must be faithful to the normal reaction of human nature. There are many scenes that would cause dangerous emotions in the minds of mature, young, or sinful individuals. Therefore, these scenes can't be demonstrated. Even within the purview of pure love, these things are considered to be unopened by the legislature.

2) Social and historical criticism: The social and historical criticism paradigm of film is a relatively mature and comprehensive model of criticism that flourished in the 1970s. The social and historical criticism paradigm of the film and television contains many contents of moral criticism and political criticism mentioned above, as well as all film theory (such as postcolonialism, structuralism, popular culture, etc.). However, it does not rigidly adhere to any model of criticism. The paradigm of social and historical criticism of film and television introduces the dimensions of sociology and history into the criticism of film and television. It takes the social and historical implication of film and television as its criticism purpose. And it would also analyze all the intrinsic elements of the audiovisual language, narrative structure and characters of the film and television, as well as the creative background, author identity and other external social and historical elements. And then, we could interpret and criticize the film and television works. Due to its openness and inclusiveness, this critique would be more profound and objective than its previous paradigm of criticism.

\section{B. The Model of Authorial Criticism}

A special approach to discuss the film emerged in the 1950s. And it affected the history of cinema criticism and the history of cinema analysis. Starting with Hitchcock album in 1954, "author theory" was defined and put into practice through "Les Cahiers du Cinema". The best example of "author theory" is the book on the work of Hitchcock by Clare Shabrol and Houmer, which are the film critics. Unlike the previous criticisms, authorial criticism is not transplanted from literary criticism. And it is produced from the cinema art.

\section{Psychoanalytic Criticism}

Film theorists have drawn psychoanalysis on semiotics in reference to Lacan's psychoanalytic theory. Louis Bodelli's publication of "Ideological Effects of Basic Film Machines" (1968) marked the establishment of the second semiotics. And it is compared with the film semiotics that brought Saussure linguistics into the field of film research (The first semiotics, whose representative work is "Film: Pure Language or Pan Language" published by Christian Mathitz in 1964, explores the classification system of film language features, code classification and lens with linguistic theory). Nick Brown once summarized the second semiotics in "The History of Film Theory" as a kind of "theory built around the relationship between film viewers and movie images". And the first semiotics proposes the analysis of symbols according to the category of those secondary (psychological) processes. Then, the second semiotics develops an analysis of the primary psychological processes of the subject.

In "The Ideological Effects of Basic Film Machines", the process of structural semiotics developing into psychoanalysis is clearly shown. By analogy, the author combines the experience of watching film with the theory of psychoanalysis: lens imaging — human vision, viewers subjects of dreams, movies - dreams, viewpoint situations - mirror stage (screen: mirror). These similarities also make it possible for psychoanalysis to enter the realm of cinematic theory. In psychoanalytic film criticism, the subject is the origin of the movie. With the existence of the desire attainment - the identification mechanism, the subject of the cinema is the master of the dream. The main target of film psychoanalysis is Hollywood classic movies and its overseas analogues — the dream.

\section{CONCLUSION}

Many Chinese film critics have taken the initiative to apply this theory of film criticism to China's film criticism. Among them, Yao Xiaotao's "New Chinese Movies: Ideological Perspectives", Wang Yichuan's "Dilemma in Living Existence — "Red Sorghum" and China's Ideological Atmosphere", Wang Hui's "Politics and Ethics and the Secrets of Its Replacement - Xie Jin's Film Analysis", Dai Jinhua's "Red Flag: An Ideological Boardwalk" and other 
four articles represent the practice of typical ideological criticism in the context of Chinese cinema.

With the diversity of the national cultures in the Third World and the specific historical orbits of various regions, it would be presumptuous to come up with "general theory" of Third World literature. However, at the beginning, we must take note of an "important distinction. That is to say, all the culture of the Third World can't be seen as anthropological independent or autonomous culture. This "cultural struggle" reflects the different phases of the economy in these regions or the modern "infiltration". Based on their situation, the cultural and material conditions of the third world do not have the psychological and subjective projections in Western culture. This point precisely illustrates the fable nature of the culture of the third world. And it tells the story of a person and personal experience. It finally contains the experience of the entire group.

\section{REFERENCES}

[1] [Russia] Gogol. "Theater Doorway" [J], translated by Guo Jiashen, "Spring Breeze", 1979.

[2] "Classical Theory of Literature and Art Collection" (Vol. 2) [M], People's Literature Publishing House, 1961.

[3] Shao Mujun. "Prohibition of Screening - Memoir of Hollywood Banned Films" [M], Shanghai Literature and Art Press, 2000.

[4] Zhang Xudong. "The cultural logic of late capitalism — Zhan Mingxin's criticism theory" [M], pp. 516 - 546, Chen Qingqiao translation, Life · Reading · New knowledge Joint Publishing, Oxford University Press, 1997. 